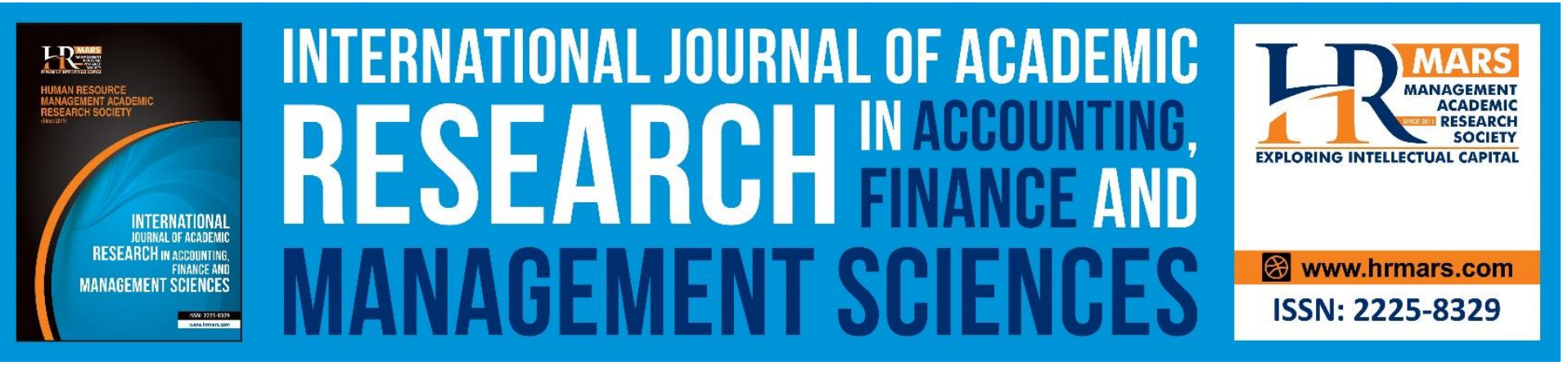

\title{
The Effects of Earnings on Share Repurchase: Evidence in Malaysia
}

Nazaria Md. Aris, Mohammad Aidid Aidi, Mohamad Jais, Razman Anuar

To Link this Article: http://dx.doi.org/10.6007/IJARAFMS/v10-i4/8160

DOI:10.6007/IJARAFMS /v10-i4/8160

Received: 10 November 2020, Revised: 11 December 2020, Accepted: 29 December 2020

Published Online: 15 January 2021

In-Text Citation: (Aris et al., 2020)

To Cite this Article: Aris, N. M., Aidi, M. A., Jais, M., \& Anuar, R. (2020). The Effects of Earnings on Share Repurchase: Evidence in Malaysia. International Journal of Academic Research in Accounting Finance and Management Sciences, 10(4), 22-39.

Copyright: (c) 2021 The Author(s)

Published by Human Resource Management Academic Research Society (www.hrmars.com)

This article is published under the Creative Commons Attribution (CC BY 4.0) license. Anyone may reproduce, distribute, translate and create derivative works of this article (for both commercial and non-commercial purposes), subject to full attribution to the original publication and authors. The full terms of this license may be seen

at: http://creativecommons.org/licences/by/4.0/legalcode

\section{Vol. 10, No. 4, 2021, Pg. 22 - 39}

http://hrmars.com/index.php/pages/detail/IJARAFMS

JOURNAL HOMEPAGE

Full Terms \& Conditions of access and use can be found at http://hrmars.com/index.php/pages/detail/publication-ethics 


\title{
The Effects of Earnings on Share Repurchase: Evidence in Malaysia
}

\section{Nazaria Md. Aris, Mohammad Aidid Aidi, Mohamad Jais, Razman Anuar}

Faculty of Economics and Business, Universiti Malaysia Sarawak, Kota Samarahan, Sarawak. Email:manazaria@unimas.my

\begin{abstract}
The aim of this study is to investigate the influence of earnings on share repurchase for firms listed in Bursa Malaysia. The dependent variable in this study is share repurchase while dividend per share, earning per share, and operating income are the proxies to earnings representing the independent variables. The analysis uses data from the time series for the period of 2014 to 2018 on an annual basis. The information is gathered using secondary data gathered from the Bursa Malaysia Terminal and accessed through the data stream. The results of this study revealed that earning per share and operating income have a significant positive effect on share repurchase. In other words, earning per share reduces the number of outstanding shares in the market while operating income encourages excess income to be spent for share repurchase activity. On the other hand, the dividend per share has an inverse impact on the share repurchase. The findings of this study not only benefit the body of knowledge and current literature but also act as a useful tool for the management and key stakeholders to influence their decisions in conducting share repurchase activity in Malaysia.
\end{abstract}

Keywords: Earnings, Dividend Per Share, Earning Per Share, Operating Income, Share Repurchase

\section{Introduction}

Share repurchase, also known as share buyback was introduced to the Malaysian market in September 1, 1997. However, not every firm manager in Malaysia is aware of the share repurchase mechanism and what advantage could it brings to the firm that announces share repurchase rather than paying dividend to the stockholders. Share repurchase has become the desired means for distribution of capital gain to the stockholders. In fact, share repurchase has outperformed cash dividend and became a Repurchase of share can be used by the managers or regulator as a tool to overcome a decreasing stock price. Thus, this research can be used by the firm to know slightly more about share repurchase. However, lately, share repurchase has become a concern to some individuals such as financial analysts, stockholders, regulatory authorities and investors. The government has used share repurchase as a mechanism to sustaining the share value in the marketplace and to boost the performance of the depressing exchange trading during the period of 
INTERNATIONAL JOURNAL OF ACADEMIC RESEARCH IN ACCOUNTING, FINANCE AND MANAGEMENT SCIENCES

Vol. 10, No. 4, 2021, E-ISSN: 2225-8329 ๑ 2021 HRMARS

the financial crisis. Another issue related to share repurchase is that some of the managers have done an inappropriate act which is announcing a share repurchase to give out a false alarm to the potential shareholders. This is because share repurchase can act as a means to increase the stock price of the firm as share repurchase declaration can produce a positive indication that the company is doing well and thus expecting the income to increase in the future and assuming stock price to be undervalued. This false signal will perhaps be making the investors suspicious of the share repurchase course. Next, another issue of share repurchase is that whether it leads to substitution or complement of dividends. Substitute dividend means that instead of paying out a dividend or special dividend to the investor, the management announces share repurchase to replace the dividend payment. Finally, even though share repurchase has been done by many firms in Malaysia especially public listed firms, some of the companies are still not aware of the regulation for the share repurchase announcement in Malaysia. For example, only one company is only permitted to do share repurchase in the open market and voting from stockholders are required in order for the firm to execute share repurchase. Other than that, share repurchase are only allowed to be financed by retained income and share premium account (Siew-Peng \& Isa, 2015). Thus, this research intends to bridge the gap between the earnings and profitability and share repurchase of listed companies in Malaysia. The general objective of this study is to investigate the influence of earnings on share repurchase for firms listed in Bursa Malaysia. The measures for earnings in this study are dividends per share, earning per share and operating income. Therefore, this study seeks for the answers to achieve the objective by developing the following three research questions;

1. How does dividend per share affect share repurchase of the firms?

2. Is earning per share influence the share repurchase of the firms?

3. Does operating income have impact on share repurchase of the firms?

Subsequently, in order to discover the answers of the research questions and ultimately achieve the aim of the study, the following specific objectives have been established:

1. To examine the effects of dividend per share to share repurchase of the firms.

2. To investigate the influence of earning per share on share repurchase of the firms.

3. To study the impact of operating income on share repurchase of the firms.

This study contributes to the body of knowledge through understanding of the literature associated to share repurchase of the firms listed in Bursa Malaysia in various manner. The results from the analysis might be used as a foundation for other researchers to conduct in-depth study in the field of Business, Accounting and Finance in Malaysia. It also contributed to the latest information regarding the share repurchase on which consequently the policymakers could use to investigate the current factors affecting share repurchase. This research has the benefit of being able to use the share repurchase data that is not accessible elsewhere. Prior research has relied on the impact of buy-back activity and not on the dollars spent on share-repurchase. The improved research can better illustrate the latest movement of share repurchase in Malaysia which evolves from unstoppable market development. Apart from an extension of the current literature, this study uncovers the critical areas for management to measure the success of management and improve the welfare of the stakeholders. Furthermore, the results of this study display the vital part of share repurchase activity 
INTERNATIONAL JOURNAL OF ACADEMIC RESEARCH IN ACCOUNTING, FINANCE AND MANAGEMENT SCIENCES

Vol. 10, No. 4, 2021, E-ISSN: 2225-8329 ๔ 2021 HRMARS

in pleasing the interest of the managers and key stakeholders, i.e., the investors, creditors and financial analysts. Changes in the movement of the variables might cause a positive or adverse impact on the company's income, thus triggering changes to the share repurchase decisions. From the management perspective, the result of this study might influence them on whether they should acquire more shares especially when they believe that the value of the stock is likely to increase. From the investor's viewpoint, it benefits the active stock traders and investors because share repurchase is one of the indicators for the undervalued stock. Hence, the knowledge of several dividend policies and how it will affect the share repurchase is essential to the market players. This therefore adds a novelty to this study, which many other researchers have not been able to explore.

\section{Literature Review}

\section{Share Repurchase in Malaysia}

Kuala Lumpur Stock Exchange (KLSE) or Bursa Malaysia has allowed share repurchasing programs after the financial crisis in Asian that happened in 1997. Section 67A was introduced in the Companies Act 1965 that allows listed companies to repurchase their share in September 1997. Nevertheless, in order for the firm to exercise the share repurchase course, shareholders agreement need to be acquired through extraordinary general meeting and the company needs to be financially stable (Edward et al., 2011). Based on Wong (2012), Malaysia legislation only allows share repurchase to be taken place in the stock exchange open market. Share repurchase program has different jurisdictions, tax law, requirements, principles, rules and markets depending on the country. Some actively exercise while others, still in the process of implementing. By using share repurchase methods, the repurchase can be done in five different ways i.e. the fixed-price tender offers, Dutch-auction tender offers, open-market share repurchase, transferable put-rights distribution and targeted stock repurchase (Wong, 2012). Fixed-price tender offers are a method where the quantity of shares is decided in advance at a particular price within some period is going to be purchased by the corporations or firms. The market value of the shares that are going to be repurchased typically lower than the pre-agreed price during the time of transaction. For the Dutch-auction tender offer, it is a bit identical to a fixed-price offer, but in Dutch-auction tender, rather than setting the price, the firm will set the range of price for the share repurchase. The interested stockholder will submit their bit price and number of stocks that they want to be offered. The corporations will then collect all the bids and will buy back the stocks at the cheapest price among the bidders. In an open-market share repurchase, instead of several stocks that are going to be repurchased, the company will repurchase the shares through a pre-agreed ringgit number of shares. It is also known as confidentially negotiated or negotiated-premium repurchase. Lastly, in transferable put-rights distribution, the corporation will release a put option to every shareholder based on the percentage of shares that they possessed. Each conveyable put-rights offers the stockholder the rightfulness to trade one stock to the corporation at a pre-agreed price and specified time. These various methods can be done for share repurchase to take place.

\section{Dividend Per Share (DPS)}

Most corporations are trying to maintain their dividends level and in fact, some of the corporations are trying to increase the dividend to please their shareholders. Corporations will take into account DPS while drafting and making their dividend policy. DPS express the add up of proclaiming dividends from the corporation for each outstanding stock. DPS is essential to the corporations and also 
INTERNATIONAL JOURNAL OF ACADEMIC RESEARCH IN ACCOUNTING, FINANCE AND MANAGEMENT SCIENCES

Vol. 10, No. 4, 2021, E-ISSN: 2225-8329 @ 2021 HRMARS

shareholders because the amount of the corporation's dividend directly translates to income for the shareholder. Also, DPS can be used as an indicator of the performance of the corporation. A high DPS means that the company can give a high return to its stockholder in the form of dividend. It is calculated through the division of the overall dividend pay-out with total outstanding share. Based on prior research, DPS is correlated with share repurchase. Accordind to Brav et al. (2005), the primary concern for the firm is to maintain the proportion of dividend in determining the dividend policies and payout ratios are the second most crucial factor. In his research's survey, eighty-eight percent of the executive agree that they will take into account the proportion of DPS when constructing their dividend policy. Repurchase decisions are also influenced by investment expenditure as the remaining cash flow. Bradley and Roberts (2004) state that DPS is a vital standard or benchmark to comply with, but the firm also must consider that the total dividend distributable might be limited by the urge to abide by debt restriction and a smooth pay-out ratio. The firm can boost its DPS before the declaration date of the dividend. In the time between the fiscal quarter yearend and the dividend declaration date, the company can boost DPS by announcing share repurchase (Liu \& Mehran, 2015). The firm usually announces its quarterly dividend around one to two months after the fiscal year as it is slighter doubt regarding their incomes. Grullon and Michealy (2002) suggest that if there is excess earning, rather than boosting the investor's dividend payment, the firm can use the excess earning to fund the share repurchase. The repurchase will not influence the dividend payout ratio, but instead, it will have a negative correlation with DPS. In this study result, shifts in DPS are supposed to be associated with the share repurchase. Therefore, the first hypothesis can be developed as;

\section{H1: There is a negative effect between DPS and share repurchase of the firms}

\section{Earnings Per Share (EPS)}

EPS measure the income or the earning per unit outstanding shares in the fiscal period. Improving EPS will attract the investor to invest in the firm as it indicates that the firm has more ability to earn the investor more profits or earnings. EPS is covered in the framework variables to calculate the correlation between EPS and share repurchase. According to Brailsford et al. (2008), a high amount of share that is planned to be purchased is related to the lower EPS. EPS can be improved through share repurchase as it can cut down outstanding shares in the market. Bens et al. (2003) suggest that EPS is a motivating factor to encourage share repurchase. This idea was supported by Mitchell and Robinson (1999) as they found that the next most common factor the managers want to repurchase shares is to improve EPS. Mitchell et al. (2001) has made a survey among Australian management and discovered that the furthermost common explanation of open market buyback of shares is to enhance EPS. As the level of EPS increases, a more substantial proportion of share is going to be repurchased throughout the buyback time. This effect is in line with the firm exercising the share repurchase mechanism to alter EPS. However, not all share repurchase is going to boost EPS. Based on Hribar et al. (2006), the effect of share repurchase on EPS can be seen in three factors which are:

i. the recorded time of the repurchase;

ii. the amount of share repurchased;

iii. the expenditure of funds for the share repurchase.

Factor (i) and (ii) will boost EPS as it reduced the number of outstanding shares, but factor (iii) will reduce EPS as the income is forfeited on the value returned to investors. Based on Grullon and Ikenberry (2000), during the declaration of share repurchase, managers usually announce the goal of 
INTERNATIONAL JOURNAL OF ACADEMIC RESEARCH IN ACCOUNTING, FINANCE AND

MANAGEMENT SCIENCES

Vol. 10, No. 4, 2021, E-ISSN: 2225-8329 @ 2021 HRMARS

the repurchase is to raise EPS. It is undeniable that share repurchase will lower the market capitalization of the firm and cause an increase in the firm's EPS. Bens, Nagar, Skinner, and Wong (2003) suggest the managers' incentives control diluted earnings per share (EPS) will influence share repurchase decisions. Mangers will increase share repurchase when encountered with the diluted effect of EPS and also when the earnings are lower than the degree needed to obtain the wanted rate of EPS growth. Based on the above discussions, the second hypothesis is constructed as;

\section{H2: There is a positive influence between EPS and share repurchase of the firms}

\section{Operating Income (OI)}

Ol or gross income is obtained from deducting the cost of production from revenue. Ol is also referred to as Earnings Before Interest \& Taxes (EBIT) i.e. it is the amount of revenue left after deducting the operational direct and indirect cost of the firm. Based on Bradley and Roberts (2004), in 1993-2001, eighty-five percent of the personal loan has a dividend restric- tion on them. For example, the dividend will not be distributed if the income of the firm is lower than the firm's interest expense. Lie (2005) has researched to investigate how the changes in dividend and share repurchase are affected by the level of operating income, and he found that they are correlated. Most of the firms that raise their pay-out level tend to have an increase in performance. Furthermore, managers will have a high tendency to raise the pay-out of the firm when they expect the likelihood of maintaining the current high level of income. The firm will choose to do share repurchase instead of raising the payment of a dividend or special dividend when they expect a smaller or uncertain about their future income. If managers expect the future income to improve and certain, they would not be reluctant to increase the pay-out as they do not need to worried about the future shortage of funds (Lie, 2005). According to Lie (2005)'s study, a firm's operating and non-operating income are higher for pay-out raising firms. He found evidence that suggests the repurchase of share is related to the positive future income changes. However, it is only bringing a small effect to the repurchase. Managers also can combine the pay-out mechanism, such as raising the dividend while also doing share repurchase, as it is associated with positive future income changes. Generally, his result found that as the pay-out gets higher than before, it will generate a positive signal about future income. The volatility of the operating income is lower for the firm that increases their pay-out level while higher for the firm that decreases their pay-out level compared to the firm that does not change their dividend or repurchase share. Thus, the third hypothesis is constructed as;

\section{H3: There is a positive impact between $\mathrm{Ol}$ and share repurchase of the firms}

\section{Theoretical Models}

There are three types of theories that have been adopted in this study to examine and understand the elements that encourage firms to repurchase their own shares. The theories are: agency theory, signalling theory and free cash flow (FCF) theory.

\section{Agency theory}

The theory of the agencies explains the conflict between managers and stockholders. This is due to the separation of power, possession and regulator in the firm as the shareholder only providing the firm with capital while managers are the ones who run the corporation's activity. The conflict arises due to the inconsistency of goals where managers aim to maximize the profits of the company, whereas shareholders tend to boost or maximize wealth. Information asymmetry between principals 
INTERNATIONAL JOURNAL OF ACADEMIC RESEARCH IN ACCOUNTING, FINANCE AND MANAGEMENT SCIENCES

Vol. 10, No. 4, 2021, E-ISSN: 2225-8329 @ 2021 HRMARS

and agents usually occur as managers are usually having more information about the corporations as they are the one who runs the company. This could lead to a greater tendency for the managers and shareholders to deviate between each other (Bebchuk and Fried, 2003). Corporations with less severe agency problems will use the advantage during their announcement of repurchase to communicate their undervaluation signal ( $\mathrm{Wu}, 2012)$. Thus, managers who have more information tend to convey or signal the information to investors. They wanted to show the investor that company worth is essentially more than the company's present market value. Thus, the firm may have the intention to lower down the information asymmetry through share repurchase (Wrońska-Bukalska \& KaźmierskaJóźwiak, 2017).

\section{Signalling theory}

Based on Fried (2009), the Signaling theory suggest that the managers announce share repurchase because they want to convey that the company's value surpasses the stock price. The information regarding the firm value can be communicated through share repurchase announcements, press conferences and filings with the regulatory agency. The Dividend Signaling Theory was also supported by (Jagannathan \& Stephens, 2003) and (Khaledi \& Darayseh, 2013). Next, Abdul Latif and Taufil Mohd (2013) suggest that managers that have private information regarding their firm will use such information to rectify the mispriced of their stock price and one of the ways is through share repurchase.

Free cash flow (FCF) theory

The free cash flow (FCF) theory suggests that the firm who have excess cash flow and has generated extra cash will tend to be less disciplined when spending the income of the firm compared to the firm that has lower cash flows and has a higher debt obligation. The share repurchase is usually used to allocate excess capital to its stockholders, thus, increasing their wealth (Yook \& Gangopadhyay, 2010). Based on the research of Grullon and Michealy (2004), firms that tend to overinvest due to the excess cash flows have a active market response to the declaration of stock repurchase and this is consistent with the Free Cash Flows Theory (FCF).According to Dittmar (2000), share repurchase is correlated with the level of cash flows. That is, as the level of cash flows increases, the tendency for the company to make a share repurchase announcement will increase. Share repurchase usually finances by the firm through its temporary cash flows whereas if the firm wants to issue dividend, it is most likely to be funded by permanent cash flows (Guay \& Harford, 2000). Through share repurchase, the firm can return the surplus cash flows to the stockholders, which will lower down the tendency of the firm's management to misused the excess cash flows and will lead to the increase in firm value (Posner, Jensen, \& Posner, 2009). In Figure 1, the theoretical model is shown to support three types of theories have been adopted in this study which are agency theory, signalling theory and free cash flow (FCF) theory. 
Independent Variable

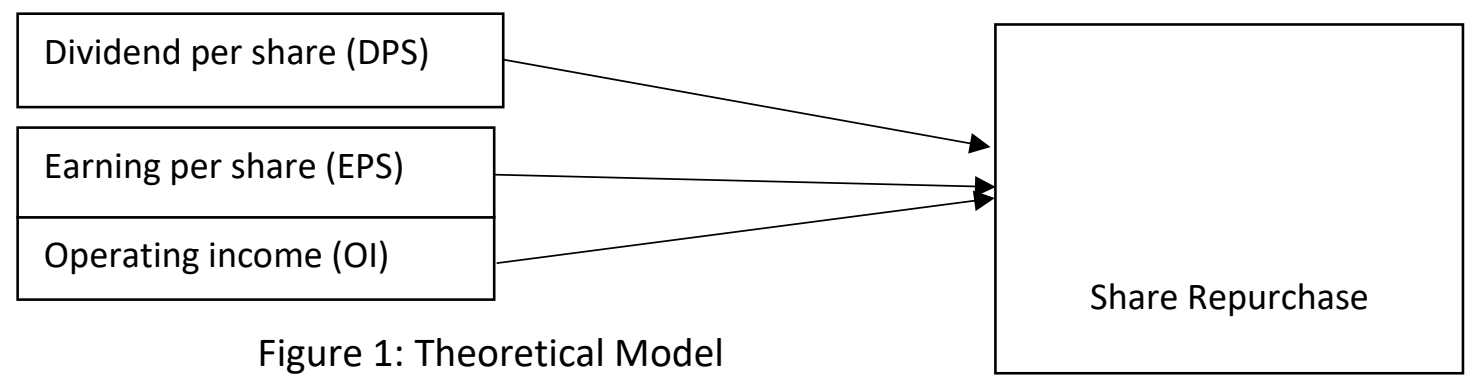

\section{Methodology of Research Research Design}

This study is mostly measuring of the qualitative information and all of the date are in numeric form. For example, ratio, mean, median and income. Variables included in this model are as follows: one independent variable (share repurchase) and three financial variables (Dividend Per Share (DPS), Earning Per Share (EPS) and operating income).

\section{Data Collection Method}

Secondary data is applied in this research, which includes the annual data from the Bursa Malaysia stock index for share repurchase. Dividend Per Share (DPS) and Earning Per Share (EPS) was obtained from the company annual report for the listed firm in Bursa Malaysia. Lastly, for the operating income, the data was collected from Bursa Malaysia under the Annual Report section, Investing.com and Data Stream. This analysis uses data from the time series, which for the period from 2014 to 2018 that was based on an annual basis and 50 companies were selected. Next, the data is sorted out in Microsoft Excel and then using E-views 10 to run the diagnostic test. Results generated are presented, analyzed, and discussed in the findings section.

\section{Estimation Model}

The linear transformed form is used in this study to estimate the connection for share repurchase, Dividend Per Share (DPS), Earning Per Share (EPS) and operating income. The performance of share repurchases, is affected by the movement of dividend per share (DPS), earning per share (EPS) and operating income. It is anticipated to see a correlated link amount all the variables. Therefore, the change in either dividend per share (DPS), earning per share (EPS) and operating income will cause the share repurchase to change. The estimation model developed for this study is as follows:

\section{Econometric Function}

Share repurchase $(\mathrm{SR})=f$ [Dividend Per Share (DPS), Earning Per Share (EPS), operating income]

2. Econometric Model

Where:

$$
\log S R_{t}=\beta_{0} \beta_{1} D P S_{t}+\beta_{2} E P S_{t}+\beta_{3} I N C_{t}+\varepsilon_{t}
$$

$\log \mathrm{SR}_{\mathrm{t}} \quad=$ Log of Share repurchase at period $\mathrm{t}$

$\beta_{1} D^{D P S} t=$ Dividend Per Share (DPS) at period $t$

$\beta_{2}$ EPS $_{t}=$ Earnings Per Share (EPS) at period $t$ 
$\beta_{3} I N C_{t} \quad=$ Operating income at period $t$

$\beta_{1}=$ intercept

$\beta_{t}=$ slope coefficients of the independent variables

$\varepsilon_{\mathrm{t}}=$ error term

$\mathrm{t}=$ number of periods

\section{Variable Definition}

\section{Share Repurchases}

The firm is declaring to the market, saying that they are buying back the outstanding stock from the current shareholder. The share buyback made by the firm usually shows the sign of positive performance and expecting the share value to go up. It shows the profitableness of the firm by building a connection between profitability and leads to share buyback.

$S R=$ Total number of unit repurchase by firm in the year

Dividend Per Share (DPS)

Dividend Per Share (DPS) is the value of dividend to be declared per outstanding shares. It is calculated using the sum of dividend paid out by the firm, inclusive a bonus dividend and interim dividend for a certain period divided by total outstanding ordinary shares.

$$
\text { DPS }=\frac{\text { Total Dividend Paid }}{\text { Total Outstanding Ordinary Shares }}
$$

Earnings Per Share (EPS)

Earnings Per Share (EPS) calculates the amount of income earned by the firm per share outstanding. Having a good Earning Per Share (EPS) will attract investors, as it indicates that the company has a good profitability ratio. It is calculated by dividing net incomes with total outstanding shares.

EPS = Net Income

Total Outstanding Ordinary Shares

\section{Operating Income}

Operating income is also known as gross income, is obtained from deducting the cost of production and operating income from revenue. It is a profit from the operation of the profit after deducting the operational cost of the firm. The operating income can be calculated using the formula below:

$$
\text { Operating Income = Gross Income- Operating Expense }
$$

\section{Data Analysis}

Descriptive Analysis

Descriptive Analysis gives the features of the specific data where it gives a conclusion about the sample data. It is a popular method when analysing the data as it gives the characteristics of the data. Mostly, researchers use this analysis to find the mean, median, mode, standard deviation, and variance of the sample data used to conduct the research. In this research, using Descriptive Statistics Analysis, we are trying to find the mean, median, mode, standard deviation and variance of the data for share repurchase, dividend per share (DPS), earning per share (EPS) and operating income using annual data from the year 2014 to 2018. 
INTERNATIONAL JOURNAL OF ACADEMIC RESEARCH IN ACCOUNTING, FINANCE AND

MANAGEMENT SCIENCES

Vol. 10, No. 4, 2021, E-ISSN: 2225-8329 @ 2021 HRMARS

\section{Correlation Matrix}

Collinearity problem of the regression can be tested with correlation matrix if the result of the regression shown $R^{2}$ is very high and a few variables are insignificant which indicate the multicollinearity problem. The table of matrix indicates the correlation of variable between other variables. The correlation of one variable with itself will state the value of 1 .

\section{Breusch-Pagan LM Test}

Breusch- Pagan LM test is a model specification between POLS and Random Effect Model. Preferred model of POLS is under null hypothesis while the preferred model of Random Effect Model is under alternative hypothesis. Breusch-Pagan LM test to measure the individual effects against the null hypothesis.

\section{Pooled Ordinary Least Squares (POLS)}

All of the model's linear-transformed variables were selected in the development of the Ordinary Least Squares (OLS) regression model. The objective of the level OLS estimate is to reveal the nonsense regression due to the empirical results were found to be spurious, then information could not be processed for other time series analyses. Such a result is known in the econometric theory as irrelevant regression results where $R^{\wedge} 2$ is higher than the model's $D-W$ statistics and such findings are unwanted for the production of an effective economic system in the economy.

\section{Random Effect Model}

REM assume that the unobserved variables are uncorrelated with observed variable which used to test the individual effect randomly. The error term of the REM is the mean value of zero and its variance. The intercept value of the firms is having common mean value of intercept and the variances of the intercept in each firm reflects in error term of REM. REM is appropriate if the sample size is pick randomly from larger sample.

\section{Hausman Test}

Hausman test is a test model specification between fixed effect model or random effect model. The null hypothesis of Hausman test is preferred model of the regression is Random Effect while the alternative hypothesis will indicate the preferred model of regression is Fixed Effect Model. The test is run to ensure the correlation between explanatory of variables with the error term.

\section{Fixed Effect Model}

Fixed effect model assumed individual specific effect of firm to be individual specific intercept estimation. FEM stated that each cross-sectional have fixed intercept value and unobserved variables may correlated with observed variables. Besides, if the sample size is not randomly selected from the larger sample, then, FEM is appropriate.

\section{Findings}

\section{Descriptive Statistics}

Table 1 illustrates the descriptive statistic for the Data used for this research. The mean, median and maximum is the highest for share repurchase followed by operating income, earning per share and the least is dividend per share. The minimum for share repurchase and dividend per share are both 0.000000 while earning per share and operating income have a negative value for their minimum. 
INTERNATIONAL JOURNAL OF ACADEMIC RESEARCH IN ACCOUNTING, FINANCE AND MANAGEMENT SCIENCES

Vol. 10, No. 4, 2021, E-ISSN: 2225-8329 @ 2021 HRMARS

The standard deviation for the set of data is ranged from 47359570 to 0.095944 . For skewness of the data, share repurchase have the highest value and followed by earning per share, dividend per share and the least is operating income. The kurtosis which shows the peak of the distribution illustrates that share repurchase are steeper compared to other variables.

Table 1. Descriptive Statistics for DPS, EPS, OI and SR

\begin{tabular}{|l|c|c|c|c|}
\hline & SR & DPS & EPS & Ol \\
\hline Mean & 10539691 & 0.058374 & 0.220554 & 173685.6 \\
\hline Median & 517850.0 & 0.030000 & 0.090250 & 30685.50 \\
\hline Maximum & $5.08 \mathrm{E}+08$ & 0.575000 & 8.190000 & 2835133 \\
\hline Minimum & 0.000000 & 0.000000 & -3.250000 & -195987.0 \\
\hline Std. Dev. & 47359570 & 0.095944 & 0.874584 & 450448.3 \\
\hline Skewness & 7.355401 & 3.714042 & 6.376129 & 3.647444 \\
\hline Kurtosis & 64.92306 & 18.25321 & 56.85143 & 17.10422 \\
\hline
\end{tabular}

\section{Coefficient Variation}

The coefficient of variation measures the standard error of sample regression function relative to the mean of the dependent variable where the smallest value of coefficient variation indicates the most preferred functional form. Table 2 shows that Log-Lin functional form has the smallest value of coefficient variation therefore it is the most preferred functional form.

Table 2. Coefficient Variation

\begin{tabular}{|c|c|}
\hline Functional Form & Coefficient Variation \\
\hline Linear & $43989860 / 10539691=4.1737$ \\
\hline Lin - Log & $45683666 / 10322757=4.42553$ \\
\hline Log - Lin & $3.254790 / 12.55218=0.2593$ \\
\hline Double Log & $3.293752 / 12.58929=0.2616$ \\
\hline Reciprocal & $0.000499 / 0.000152=3.2829$ \\
\hline
\end{tabular}

\section{Correlation Matrix}

Refering to Table 3 , DPS shows a negative relationship with share repurchase while EPS and OI show a positive relationship with share repurchase. However, DPS and EPS are only significant using 5\% significant level while OI is positively significant at $10 \%$ significant level. On the other hand, EPS and OI shown a positively insignificant relationship with DPS. This means that any increase or decrease in earnings per share and operating income will not trigger any changes to DPS. Lastly, OI shows a significant positive relationship with EPS using $10 \%$ significant level.

Table 3. Correlation between DPS, EPS, OI and SR

\begin{tabular}{|c|c|c|c|c|}
\hline & LGSR & DPS & EPS & OI \\
\hline LGSR & 1 & & & \\
\hline DPS & $-0.025621^{* *}$ & 1 & & \\
\hline EPS & $0.033098^{* *}$ & 0.134516 & 1 & 1 \\
\hline OI & $0.057606^{*}$ & 0.418054 & $0.065912^{*}$ & \\
\hline
\end{tabular}

Notes:*and** denote statistically significant at $10 \%$ level and $5 \%$ level respectively. 
INTERNATIONAL JOURNAL OF ACADEMIC RESEARCH IN ACCOUNTING, FINANCE AND

MANAGEMENT SCIENCES

Vol. 10, No. 4, 2021, E-ISSN: 2225-8329 @ 2021 HRMARS

\section{Breusch- Pagan Lagrange Multiplier (LM) Test}

Breusch-Pagan test is conducted to test the best regression model between POLS and REM. Table 4 Breusch-Pagan LM Test shows the chi-square of 91.47233 with a p-value of 0.000 which is less than $1 \%$ significance level. This indicates that we must reject the null hypothesis of no cross-sectional effect. Thus, REM is more preferred model compared to the POLS model.

Table 4. Breusch-Pagan Lagrange Multiplier (LM) Test

\begin{tabular}{|c|c|c|c|}
\hline & Cross-section & Time & Both \\
\hline \multirow{2}{*}{ Breusch-Pagan } & 91.47233 & 0.684141 & 92.15647 \\
& $(0.000)$ & $(0.4082)$ & $(0.0000)$ \\
\hline
\end{tabular}

Notes:*and** denote statistically significant at $10 \%$ level and $5 \%$ level respectively.

\section{Pooled Ordinary Least Squares (POLS) Regression Model}

Table 5 shows the Pooled Ordinary Least Squares (POLS) Regression Model result. There is a negative relationship between DPS and share repurchase. However, the result for EPS and OI show a positive relationship with share repurchase. The result indicates that share repurchase will increase by $20.4 \%$ if DPS decrease by $1 \%$. On the other hand, if EPS and OI increase by $1 \%$, it will also increase share repurchase as much as $2.32 \%$ and $5.23 \%$ respectively. From the result, EPS are statistically significant at $10 \%$ significant level while for DPS and OI are significant at a significant level of $1 \%$. All of the independent variables are significant as their $p$-values which are $0.0084,0.0969$ and 0.0007 are more than the critical value.

Table 5. Pooled Ordinary Least Squares (POLS) Regression Model Result

\begin{tabular}{|c|c|c|c|c|}
\hline Variables & Coefficient & $\begin{array}{c}\text { Standard } \\
\text { error }\end{array}$ & t-statistic & Prob. \\
\hline DPS & $-20.40012 * * *$ & 7.404802 & -2.754985 & 0.0084 \\
\hline EPS & $2.315254^{*}$ & 1.366078 & 1.694818 & 0.0969 \\
\hline Ol & $5.23 \mathrm{E}-06 * * *$ & $1.43 \mathrm{E}-06$ & 3.656023 & 0.0007 \\
\hline $\mathrm{C}$ & $12.79557 * * *$ & 0.619854 & 20.64287 & 0.0000 \\
\hline $\mathrm{R}^{2}$ & \multicolumn{4}{|c|}{0.260535} \\
\hline F-statistics & \multicolumn{4}{|c|}{$5.402380(0.002865)$} \\
\hline
\end{tabular}

Notes:*and*** denote statistically significant at $10 \%$ level and $1 \%$ level respectively.

From the study conducted, the R-squared of this model is 0.260535 . This indicates that $26.05 \%$ of share repurchase can be explained by DPS, EPS and OI. F-statistics shows the value of 5.402380 with a probability of 0.002865 which is lesser than $1 \%$ significant level indicates the rejection rule of null hypothesis hence, conclude that at least one independent variable is useful to predict share repurchase. Therefore, the equation for POLS Model can be constructed as:

$$
\mathrm{SR}_{\mathrm{it}}=12.80-20.40 \mathrm{DPS}_{\mathrm{t}}+2.32 \mathrm{EPS}_{\mathrm{it}}+5.23 \mathrm{Ol}_{\mathrm{it}}
$$

\section{Random Effect Model (REM)}

Table 6 shows the regression result of REM model. There is a positive relationship between the dependent variable share repurchase and independent variable EPS and OI. However, DPS has a negative relationship with share repurchase. The result indicates that when EPS and OI increases by 
INTERNATIONAL JOURNAL OF ACADEMIC RESEARCH IN ACCOUNTING, FINANCE AND MANAGEMENT SCIENCES

Vol. 10, No. 4, 2021, E-ISSN: 2225-8329 @ 2021 HRMARS

$1 \%$, it will also increase share repurchase as much $10.61 \%$ and $4.41 \%$ respectively but when DPS increase by $1 \%$, share repurchase will decrease for $0.37 \%$. From the result, all of the variables are significant as all their $p$-values are below $1 \%$ significant level for OI, and below 5\% for DPS and EPS. From the study conducted, the R-squared of this model is 0.193115 . This indicates that $19.31 \%$ of share repurchase can be explained by DPS, EPS and OI. F-statistics shows the value of 7.578926 with a probability of 0.000134 which is lesser than $1 \%$ significant level indicates the rejection rule of null hypothesis hence, conclude that at least one independent variable is useful to predict share repurchase. Therefore, the equation for the REM model can be constructed as:

$$
\mathrm{SR}_{\mathrm{it}}=12.32-0.37 \mathrm{DPS}_{\mathrm{t}}+10.61 \mathrm{EPS}_{\mathrm{it}}+4.41 \mathrm{Ol}_{\mathrm{it}}
$$

Table 6. Random Effect Model (REM) Result

\begin{tabular}{|c|c|c|c|c|}
\hline Variables & Coefficient & Standard error & t-statistic & Prob. \\
\hline DPS & $-0.372000^{* *}$ & 0.133829 & -2.779670 & 0.0066 \\
\hline EPS & $10.60840^{* *}$ & 3.547588 & 2.990313 & 0.0035 \\
\hline OI & $4.41 \mathrm{E}-06^{* * *}$ & $8.11 \mathrm{E}-07$ & 5.428856 & 0.0000 \\
\hline $\mathrm{C}$ & 12.31876 & 0.423607 & 29.08063 & 0.0000 \\
\hline $\mathrm{R}^{2}$ & \multicolumn{5}{|c}{0.193115} \\
\hline F-statistic & $7.578926(0.000134)$ \\
Notes: ${ }^{* *}$ and ${ }^{* *}$ denote statistically significant at 5\% level and 1\% level respectively.
\end{tabular}

\section{Hausman Test}

Hausman test result in Table 7 shows chi-square of 4.462919 with a p-value of 0.2156 which is more than $10 \%$ significance level indicates that we cannot reject the null hypothesis of error terms are uncorrelated with estimators. There is no correlation between error terms and some estimators thus, REM is more favorable than FEM. Therefore, REM is an appropriate model to use in this study.

Table 7. Hausman Test Result

\begin{tabular}{|c|c|c|}
\hline & Chi-square statistic & Prob \\
\hline Hausman Test & 4.462919 & 0.2156 \\
\hline
\end{tabular}

\section{Fixed Effect Model (FEM)}

Table 8 shows the regression result of the FEM model. There is a positive relationship between the dependent variable share repurchase and independent variable EPS and OI while negative relationship for DPS. The result indicates that when DPS increase by $1 \%$, it will reduce share repurchase as much as $0.67 \%$. On the other hand, if EPS and OI increase by $1 \%$, it will increase share repurchase as much as $10.59 \%$ and $1.19 \%$ respectively. From the result, all of the variables are significant with share repurchase. DPS is significant at $10 \%$ significant level as its p-value (0.0862) is less than critical value 0.10 . For EPS and OI, both are significant using $5 \%$ significant level as their $p$ value ( 0.006 and 0.008 respectively) are less than 0.05 critical value. 
INTERNATIONAL JOURNAL OF ACADEMIC RESEARCH IN ACCOUNTING, FINANCE AND MANAGEMENT SCIENCES

Vol. 10, No. 4, 2021, E-ISSN: 2225-8329 @ 2021 HRMARS

Table 8. Fixed Effect Model (FEM)

\begin{tabular}{|c|c|c|c|c|}
\hline Variables & Coefficient & Standard error & t-statistic & Prob. \\
\hline DPS & $-0.667866^{*}$ & 0.385267 & -1.733516 & 0.0862 \\
\hline EPS & $10.58664^{* *}$ & 3.765182 & 2.811720 & 0.0060 \\
\hline OI & $1.19 \mathrm{E}-05^{* *}$ & $4.35 \mathrm{E}-06$ & 2.724083 & 0.0076 \\
\hline C & 10.43763 & 0.692099 & 15.08112 & 0.0000 \\
\hline $\mathrm{R}^{2}$ & \multicolumn{4}{|c|}{0.699471} \\
\hline F-statistic & \multicolumn{4}{|c}{} \\
\hline
\end{tabular}

Notes:*and** denote statistically significant at $10 \%$ level and $5 \%$ level respectively.

From the study conducted, the R-squared of this model is 0.699471 . This indicates that $69.95 \%$ of share repurchase can be explained by DPS, EPS and OI, the rest can be explained by error term which is $30.05 \%$. F-statistics shows the value of 4.341619 with a probability of 0.00000 which is lesser than $1 \%$ significant level indicates the rejection rule of null hypothesis hence, conclude that at least one independent variable is useful to predict share repurchase. Therefore, the equation for the FEM model can be constructed as:

$\mathrm{SR}_{\mathrm{it}}=10.44-0.67 \mathrm{DPS}_{\mathrm{t}}+10.59 \mathrm{EPS}_{\mathrm{it}}+1.19 \mathrm{Ol}_{\mathrm{it}}$

\section{Summary of Regression Model Discussion}

Table 9 shows the three different models used in this study i.e. Pooled Ordinary Least Square (POLS), Random Effects Model (REM) and Fixed Effects Model (FEM).

Table 9. Summary of Regression Model

\begin{tabular}{|c|c|c|c|}
\hline \multirow{2}{*}{ Independent Variable } & \multicolumn{2}{|c|}{ Dependent variable: Share Repurchase } \\
\cline { 2 - 4 } & POLS & $\begin{array}{c}\text { Random Effects } \\
\text { Model }\end{array}$ & $\begin{array}{c}\text { Fixed Effect } \\
\text { Model }\end{array}$ \\
\hline DPS & $-20.40012^{* * *}$ & $-0.372000^{* *}$ & $-0.667866^{*}$ \\
\hline EPS & $2.315254^{*}$ & $10.60840^{* *}$ & $10.58664^{* *}$ \\
\hline OI & $5.23 \mathrm{E}-06^{* * *}$ & $4.41 \mathrm{E}-06^{* * *}$ & $1.19 \mathrm{E}-05^{* *}$ \\
\hline CONSTANT & $12.79557^{* * *}$ & 12.31876 & 10.43763 \\
\hline $\mathrm{R}^{2}$ & 0.260535 & 0.193115 & 0.699471 \\
\hline F-statistic & 5.402380 & 7.578926 & 4.341619 \\
$(0.002865)$ & $(0.000134)$ & $(0.000000)$ \\
\hline $\begin{array}{c}|c| \\
\text { Breusch-Pagan Lagrange } \\
\text { Multiplier Test }\end{array}$ & $91.47233(0.000)$ & \\
\hline Hausman Test & \multicolumn{3}{|c|}{$4.462919(0.2156)$} \\
\hline
\end{tabular}

Notes:*,**and*** denote statistically significant at $10 \%$ level, $5 \%$ level and $1 \%$ level respectively. Based on the most preferable model which is REM, DPS shows a significant negative relationship with share repurchase by using $1 \%$ significant level. This indicates that the firm cannot issue dividend payout simultaneously while doing share repurchase activity. This is because almost all the firm in Malaysia will try to maximize dividend payout to their shareholders to communicate that the firm is in good condition and growing based on their evaluation (Ofer \& Thakor, 1987). If the firm is going to increase the dividend payout to the shareholder from the surplus earning from the operational 
INTERNATIONAL JOURNAL OF ACADEMIC RESEARCH IN ACCOUNTING, FINANCE AND

MANAGEMENT SCIENCES

Vol. 10, No. 4, 2021, E-ISSN: 2225-8329 @ 2021 HRMARS

activity, the board of management will reduce or call off their share repurchase activity as the fund will be allocated for the dividend payout. However, if the management presumes that their stock price is being undervalued, they will most likely be implementing share repurchase instead of dividend payout. This is because share repurchase activity will become one of the indicators that suggest the firm performance is improving (Grullon \& Michealy, 2002).

Next, from the result, EPS has a significant positive relationship with share repurchase. This might be due to the management usually uses share repurchase to boost EPS of their firm. By doing share repurchase, the firm can reduce its share outstanding in the market and thus increasing their earnings ratio. When a higher EPS elevates, they are confident about their future earnings growth. This is consistent with prior research made by Bens et al in 2003. A survey has been conducted among the managers in Australia and the result found was the most common motive of the open market repurchase is to enhance the firm EPS. He suggested that the main objective management are issuing share repurchase is because they want to improve their firm's EPS through share repurchase activity. It can be enhanced as share repurchase can reduce the number of outstanding shares in the market. Lastly, the study discovered that operating income has a positive relationship with share repurchase. In other words, when profitability is on an upswing, firms tend to repurchase its own shares in the marketplace. This is because when operating income of the firm increase, the firm will most likely to have an excess income to be spent for share repurchase activity. This is because the manager will be using the excess fund from their operating income to carried on share repurchase activity. This is consistent with the prior research findings which strongly agreed that the determinant of share repurchase activity to be carried out is influenced by future income of the firm and if the managers are satisfied about the deficit of funds in the future, they would not be reluctant to raise their payout or share repurchase activity (Lie, 2005).

\section{Conclusion}

The aim of this study was to analyse the effects of earnings (dividend per share, earning per share, and operating income) that can be considered relevant to the performance of share repurchase from 2014 to 2018 for firms' listed on Bursa Malaysia. The findings revealed that there is a significant inverse effect between dividend per share (DPS) and share repurchase which is consistent with prior research. The result of the study also signifies that earnings per share (EPS) and operating income (OI) have a positive influence on share repurchase. As predicted by free cash flow (FCF) theory, this study depicts that FCF can be distributed through dividends or repurchase of shares, but sometimes management does not do so and instead uses it to manage wealth, such as bonuses and investments that can increase control and reduce the possibility of takeover.

The current study was not without limitations. The collection of data that are unavailable in the Data Stream especially for the number of shares repurchase as not all of the firms are involved with share repurchase every year and giving out a dividend at the end of the accounting period. As the study is conducted on the listed company in Bursa Malaysia, the data for the share repurchase has been extracted manually from the websites. This makes the research took a longer period to extract and organize the data based on the years of study which is between 2014 to 2018. Next, the latest data from 2019 and 2020 were excluded from the research because some of the firms have not disclosed their annual report and share repurchase activities for the recent year. The total firms that have been selected for this research are 50 firms, where it is only $5.36 \%$ from the total listed company in Bursa Malaysia (Total of 932 companies listed in 2020). Therefore, the sample size for this research is 
INTERNATIONAL JOURNAL OF ACADEMIC RESEARCH IN ACCOUNTING, FINANCE AND MANAGEMENT SCIENCES

Vol. 10, No. 4, 2021, E-ISSN: 2225-8329 ๑ 2021 HRMARS

relatively smaller due to some companies have not carried any share repurchase activities, new companies, unavailability of data and time constraint of the research. Another limitation of this study, there are still many other variables that influence the share repurchase of the companies but this study only considers three independent variables for share repurchase assessment. Therefore, the ability of the independent variables in explaining variations in share repurchase is limited. There is also no control variables in this study that might bias the results. Control variables are paramount to identify the effects of independent variables on a dependent variable. This would be difficult for future researcher to replicate this study in similar way. Future studies might expand the sample data of this study to be at least more than half of the companies listed in Bursa Malaysia or if the research is focusing on a sector, the companies selected must be more than half of the companies in that sector. This is to make sure the result is more accurate and valid. Other than that, the period for this study is proposed to be longer than 5 years to ensure the precision of the research and able to fill the unavailable data the data sample at the period studied. In the coming years, future lines research should expand this study in other countries especially in the developed countries such as Japan, United Kingdom, China, United States and others as they have a very strong economy where it is very useful to see the actual behaviors, benefits and factors affecting share repurchase. Besides, this study can also be conducted by focusing on different sectors to estimate the variability of the result between different sectors such as healthcare, technology, petroleum and others. Finally, subsequent studies might want to consider extending the independent variables that are predicted to affect share repurchase assessment, for example, liquidity (using current ratio indicator) and growth (using growth indicators). As for the control variables, elements such as firms' size, leverage, board size or other factors should be included to accurately test the value of the independent variables of this study i.e. DPS, EPS and OI that might have influence on share repurchase, the dependent variable.

Overall, as the share repurchase decreases the outstanding shares of the firms, the most important effect on the profitability measures per share, such as earnings per share and operating income matters if the firms aim to satisfy the shareholders. Firms that are too vigorously repurchase its own shares could be careless in protecting their shareholders' best interests compared to firms that repurchase shares in the most restrictive condition. Similarly, while dividends are in the form of a cash pay-out, the repurchase of shares enables shareholders to sell the shares and remove them off the market. This could lead to a propagating force on share prices, due to the reduced and limited shares available in the market place.

\section{Acknowledgement}

This research study is supported by Universiti Malaysia Sarawak (UNIMAS) Special Short Term Grant (F01/SpSTG/1574/2017)

\section{References}

Abdul Latif, R., \& Mohd, T. K. (2013). Signaling and substitution hypotheses in Malaysian share repurchases. Management, 3(2), 99-104. https://doi.org/10.5923/j.mm.20130302.06

Asquith, P., \& Mullins, D. W. (1986). Signalling with dividends, stock repurchases, and equity issues. Financial Management, 15(3), 27. https://doi.org/10.2307/3664842

Babenko, I. (2009). Share repurchases and pay-performance sensitivity of employee compensation contracts. Journal of Finance, 64(1), 117-151.

Bathala, C. T., Moon, K. P., \& Rao, R. P. (1994). Managerial ownership, debt policy, and the impact of 
INTERNATIONAL JOURNAL OF ACADEMIC RESEARCH IN ACCOUNTING, FINANCE AND

MANAGEMENT SCIENCES

Vol. 10, No. 4, 2021, E-ISSN: 2225-8329 ๑ 2021 HRMARS

institutional holdings: An agency perspective. Financial Management, 23(3), 38-50.

Bebchuk, L., \& Fried, J. (2003). Executive compensation as an agency problem. Journal of Economic Perspectives, 17(3), 71-92.

Bens, D. A., Nagar, V., Skinner, D. J., \& Wong, M. H. F. (2003). Employee stock options, EPS dilution and share repurchases. Journal of Accounting and Economics, 36(1-3), 51-90.

Bhana, N. (2007). The market reaction to open market share repurchases announcements: The South African experience. Investment Analysts Journal, 65, 25-36.

Bradley, M., \& Roberts, M. R. (2004). The structure and pricing of corporate debt covenants. 6th Annual Texas Finance Festival.

Brailsford, T., Marchesi, D., Simon, A., \& Tutticci, I. (2008). The determinants of share repurchase decisions in on-market buy-backs. The University of Queensland Working Paper.

Brav, A., Graham, J. R., Harvey, C. R., \& Michaely, R. (2005). Payout policy in the 21st century. Journal of Financial Economics, 77(3), 483-527.

Fried, J. M. (2009). Open market repurchases: Signaling or managerial opportunism? Theoretical Inquiries in Law, 2(2). https://doi.org/10.2202/1565-3404.1039

Guay, W., \& Harford, J. (2000). The cash-flow permanence and information content of dividend increases versus repurchases. Journal of Financial Economics, 385-415.

Grullon, G., \& Michaely, R. (2004). Information content of share repurchase program. The Journal of Finance, 651-680.

Grullon, G., \& Ikenberry, D. (2000). What do we know about stock repurchases? Journal of Applied Corporate Finance, 13(1), 31-51.

Grullon, G., \& Michaely, R. (2002). Dividends, share repurchases, and the substitution hypothesis. The Journal of Finance, 57(4), 1649-1684.

Hribar, P., Jenkins, N. T., \& Johnson, W. B. (2006). Stock repurchases and earnings management device. Journal of Accounting and Economics, 41, 3-27.

Jagannathan, M., \& Stephens, C. (2003). Motives for multiple open-market repurchase programs. Financial Management, 32(2).

Khaledi, N., \& Darayseh, M. (2013). Information content of share repurchases. Economics, Management, and Financial Markets, 8(3).

Lie, E. (2005). Financial flexibility, performance, and the corporate payout choice. Journal of Business, 78(6), 2179-2203. https://doi.org/10.1086/497043

Mitchell, J. D., \& Robinson, P. (1999). Motivations of Australian listed companies effecting share buybacks. Abacus 35, 91-119.

Mitchell, J. D., Dharmawan, G. V., \& Clarke, A. W. (2001). Managements' view on share buy-backs: An Australian survey. Accounting and Finance, 41, 93-129.

Liu, N., \& Mehran, J. (2015). Does dividend policy drive repurchases? An empirical study. Managerial Finance, 42(1), 13-22. https://doi.org/10.1108/MF-10-2015-0258

Ofer, A. R., \& Thakor, A. (1987). A theory of stock price responses to alternative corporate cash disbursement methods: Stock repurchases and dividends. Journal of Finance, 42(2).

Posner, R. A., Jensen, M. C., \& Posner, R. A. (2009). Agency costs of free cash flow, corporate finance, and takeovers. Corporate Bankruptcy, 11-16. https://doi.org/10.1017/cbo9780511609435.005

Ross, S. (1977). The determination of capital structure: the incentive-signalling approach. Bell Journal of Economics, 8(1). 
INTERNATIONAL JOURNAL OF ACADEMIC RESEARCH IN ACCOUNTING, FINANCE AND

\section{MANAGEMENT SCIENCES}

Vol. 10, No. 4, 2021, E-ISSN: $2225-8329$ @ 2021 HRMARS

Siew-Peng, L., \& Isa, M. (2015). Management perceptions of share repurchases in emerging markets:

The case for Malaysia. Asian Academy of Management Journal of Accounting and Finance, 11(1), 97-121.

Vermaelen, T. (1981). Common stock repurchases and market signaling: An empirical study. Journal of Financial Economics, 139-183.

Wong, W. W. E. (2012). Share Repurchase and Firm Performance in Malaysia [Master's thesis, Universiti Malaysia Sarawak]. UNIMAS Institutional Repository http://ir.unimas.my/id/eprint/9068

Wu, R. S. (2012). Agency theory and open-market share repurchases: Evidence from Taiwan. Emerging Markets Finance and Trade, 48(2), 6-23. https://doi.org/10.2753/REE1540496X48S201

Wronska-Bukalska, E., \& Kazmierska-Jozwiak, B. (2017). Signaling hypotheses of share repurchase life cycle approach. The case of Polish listed companies. Equilibrium. Quarterly Journal of Economics and Economic Policy, 12(2), 245-257.

Yook, K., \& Gangopadhyay, P. (2010). Free cash flow and the wealth effects of stock repurchase announcements. Quarterly Journal of Finance and Accounting, 49(3/4), 23-42. 